\title{
Sulfide detoxification and tolerance in Nereis (Hediste) diversicolor and Nereis (Neanthes) virens (Annelida: Polychaeta)
}

\author{
Bent Vismann \\ Marine Biological Laboratory, University of Copenhagen, Strandpromenaden 5, DK-3000 Helsinger, Denmark
}

\begin{abstract}
Sulfide oxidation activity was quantified for different tissues of the polychaetes Nereis diversicolor and $N$. virens. Blood, intestinal wall and intestinal fluid of both species catalyzed sulfide oxidation. $N$. diversicolor showed a significantly higher activity than did $N$. virens. Sulfide oxidation activity in the blood correlated with the concentration of 'brown pigment' $N$. diversicolor was more tolerant to long-term exposure to hypoxia and to hypoxia in the presence of sulfide than $N$. virens, and was twice as tolerant as $N$. virens to short-term exposure to high concentrations of sulfide. Results are discussed in terms of habitat preferences and competitive interactions.
\end{abstract}

\section{INTRODUCTION}

The discovery of the macrofauna associated with sulfide-emitting deep-sea hydrothermal vents (Lonsdale 1977, Corliss et al. 1979, Edmond et al. 1982) has stimulated research on physiological adaptations to sulfide in aerobic marine organisms. The effluent dispersal of hydrothermal vents is rich in hydrogen sulfide, and sulfide is known to be extremely toxic to most aerobic organisms in nanomolar to micromolar concentrations (National Research Council 1979). Toxicity is due to the inhibition of metalloenzymes, notably cytochrome oxidase and blood pigments (Evans 1967). The vent fauna is found in the unstable mixture of sulfide from the vent dispersal and oxygen from the surrounding deep sea. Aerobic life therefore depends on the ability to detoxify hydrogen sulfide, as it is impossible to prevent it from entering the organism (Powell et al. 1979). Different mechanisms for sulfide detoxification in hydrothermal vent animals have been described; these include endo- and ectosymbiontic sulfide-oxidizing bacteria, and enzymatic sulfide oxidation involving blood pigments and animal enzymes of the midgut gland and mitochondrial oxidation (e. g. Jones 1985).

Sulfide has always been a component of the biosphere and it is omnipresent in sediments and in anoxic water (Fenchel \& Riedl 1970), and all benthic animals may to a varying degree be exposed to the compound in the external environment. Actually, all metazoa seem to be capable of catalyzing sulfide oxidation since it is produced as a by-product in the degradation of sulfur-containing proteins, certain coenzymes and metabolites, and sulfide is produced by microbial fermentation in the alimentary canal (Siegel 1975). Thus a sulfide oxidase, related to that of Thiobacillus, oxidizing sulfide to thiosulfate, has been demonstrated in the liver and kidney of rats (Baxter et al. 1958a, b, Sörbo 1958) and, exposed to sulfide, dogs and rats have been shown to excrete sulfate in the urine (Dziewiatkowski 1945, Yokoyama et al. 1971, Curtis et al. 1972). Sulfide is also oxidized by blood plasma of vertebrates (Haggard 1921, Evans 1967).

Marine sediments are typically anoxic a few mm or $\mathrm{cm}$ beneath the surface and contain high (up to $10 \mathrm{mM}$ ) concentrations of sulfide (Fenchel \& Riedl 1970), and under some circumstances the sulfide zone may extend up into the water column (Fenchel 1969, Jørgensen 1977. Hansen et al. 1978). The sulfide is principally produced by sulfate-respiring bacteria, but a small fraction derives from the fermentation of proteins (Fenchel 1969). Invertebrates that burrow in sediments are therefore likely to be exposed to sulfide and even tubedwelling forms which maintain their tubes oxidized by irrigation (Meyers et al, 1987, 1988) will be exposed when establishing themselves in the sediment.

There is evidence that animals living in sulfide-rich sediments show an increased tolerance to this toxic compound (Jacubowa \& Malm 1931, Theede et al. 
1969, Oertzen \& Schlungbaum 1972). Enzymatic catalysis of sulfide oxidation has also been demonstrated in Arenicola marina (Patel \& Spencer 1963b), in representatives of the meiofauna (gnathostomulids, turbellarians and gastrotrichs) (Powell et al. 1979, 1980), in crustaceans (Vetter et al. 1987), in molluscs (Anderson et al. 1987, Powell \& Somero 1985, 1986, Powell \& Arp 1989) and in echiuroids (Powell \& Arp 1989), while high tolerance to sulfide is also indicated in tubificids and priapulids (Degn \& Kristensen 1981, Oeschger \& Schmaljohann 1988).

Finally, representatives of a variety of phyla harbor sulfide-oxidizing bacteria (including pogonophorans, molluscs, oligochaetes, nematodes, and ciliates) either as ectosymbionts or in specialized tissues (e.g. Cavanaugh 1985, Southward 1987). In evaluating the adaptive significance of the symbiotic relationships, most emphasis has been that of host nutrition, but the bacteria must also function by detoxifying sulfide, thus protecting the host. It is possible that during the evolution of these relationships, detoxification initially represented the adaptive significance for the animal host.

Sulfide toxicity and detoxification have many important implications for the ecology of benthic animals and pose several unresolved physiological problems. Here I describe the ability to detoxify sulfide in 2 congeneric polychaetes in relation to their distribution in nature.

The tube-dwelling nereid polychaetes Nereis (Neanthes) virens Sars and Nereis (Hediste) diversicolor Müller occur abundantly in coastal sediments of Northern Europe (Hartmann-Schröder 1971). N. virens prefers oxidized sandy substrates (Rasmussen 1973, Kristensen 1988) while $N$. diversicolor is usually found in the innermost parts of estuaries and fjords in different types of sediment, but it prefers silty sediments with a high content of organic matter (Rasmussen 1973, Kristensen 1988).

The objectives of the present study were to quantify the activity of sulfide detoxification in different tissues in the 2 species and to compare their ability to detoxify sulfide, in relation to their respective tolerances to sulfide exposure and their distribution in nature.

\section{MATERIALS AND METHODS}

Sampling. Nereis diversicolor and $N$. virens were sampled in Vellerup Bay, Isefjorden, Denmark, at water depths of 0.3 to $1.3 \mathrm{~m}$. In the laboratory they were kept in tanks with natural sediment and running seawater $\left(7\right.$ to $10^{\circ} \mathrm{C}, \mathrm{S}: 28 \pm 1 \%$ ) for up to 2 wh prior to the experiments. They were fed pieces of mussel 1 or 2 times weekly

Sulfide oxidation activity. Catalysis of sulfide oxidation was quantified on homogenates of body wall, intestinal wall, or whole specimens, on blood, and on fluid samples of the coelomic cavity or from the anterior region of the intestine. All types of samples were prepared in a buffer (pH: 8.0,50 mM TRIS/HCl and $0.1 \%$ of the laboratory detergent 'Prox'). Samples were centrifuged for $10 \mathrm{~min}$ at $1700 \times g$ to remove particles. Sulfide oxidation was measured colormetrically at $20^{\circ} \mathrm{C}$ using benzyl viologen (1.1' dibenzyl-4.4'-bipyridinium), which is colorless when oxidized and purple when reduced. In the assay it acts as an alternative to $\mathrm{O}_{2}$ as electron acceptor from sulfide $\left(\mathrm{E}^{\prime}{ }_{0}=-0.36 \mathrm{mV}\right)$, but it is rapidly reoxidized in the presence of oxygen (Peck 1968). The colormetric analysis was thus performed under anoxic conditions. The reduction of benzyl viologen was measured using a spectrophotometer (Unicam SP 1800) at a wavelength of $578 \mathrm{~nm}$ and an extinction coefficient of 8.65 absorbance units $\mathrm{mM}^{-1}$ $\mathrm{cm}^{-1}$ (McKellar \& Sprott 1979). Results were corrected for blank oxidation and expressed as $\mu$ moles of substrate converted to product per minute per fresh weight of biological material at $20^{\circ} \mathrm{C}$. Substrate concentrations were $5.5 \mathrm{mM}$ or less as the non-enzymatic sulfide oxidation and concomitant reduction of benzyl viologen becomes appreciable at higher sulfide levels (Powell \& Somero 1985). The reaction mixture contained $40 \mathrm{mM}$ glycine/ $\mathrm{NaOH}$ buffer $\mathrm{pH}=9.0,2 \mathrm{mM}$ benzyl viologen, 0 to $5.5 \mathrm{mM} \mathrm{Na}_{2} \mathrm{~S}$, and 100 to $200 \mu \mathrm{l}$ sample in a total volume of $2 \mathrm{ml}$. Concentrations of $\mathrm{Na}_{2} \mathrm{~S}$ were determined by potentiometric titration with $\mathrm{AgNO}_{3}$ using an Ag-AgS electrode and a potentiometer (Radiometer ion85). The term 'sulfide' here refers to all species of sulfide present in the reaction mixture $\left(\mathrm{H}_{2} \mathrm{~S}, \mathrm{HS}^{-}\right.$, and $\mathrm{S}^{2-}$ ). All biological materials show some sulfide oxidation activity due to non-specific catalysis by proteins and metal ions. Therefore, a benzyl viologen assay of sulfide oxidation activity (sulfide concentration = $5 \mathrm{mM}$ ) in homogenates of Mytilus edulis $\mathrm{L}$, which lives in sulfide-free environments, was performed to define a basal level of sulfide oxidation activity in animal tissue. The activity in $M$. edulis was $0.20 \pm 0.05$ (SE) $\mu \mathrm{mol}$ min $^{-1} \mathrm{FW} \mathrm{g}^{-1}$, i. e. the same basal level as found in Mercenaria mercenaria by Powell \& Somero (1985).

Blood. Pure vertebrate hemoglobin exposed to sulfide will form sulfhemoglobin, which cannot carry oxygen (Haggard 1921, Sörbo 1958, Patel \& Spencer 1963b. Wells \& Pankhurst 1980). In whole blood, however, a factor resident in the plasma protects the hemoglobin, and the blood oxidizes sulfide to the level of elemental sulfur and thiosulfate, until lethal doses of sulfide are reached (Sörbo 1958). Blood from the polychaetes Arenicola marina and Abarenicola affinis does not form sulfhemoglobin (Patel \& Spencer 1963a, Wells \& Pankhurst 1980). Instead, the hemoglobin in $A$. marina forms a pigment, which Patel \& Spencer (1963a) termed 'brown pigment' According to Patel \& Spencer 
the pigment catalyzes the oxidation of sulfide to elemental sulfur and thiosulfate and can be taken as a biochemical adaptation to high concentrations of sulfide. However, the pigment is not formed by the hemoglobin in $A$. affinis and the biological significance of the pigment is refuted by Wells \& Pankhurst (1980) (see 'Results and discussion' for further details). According to Patel \& Spencer (1963a) the brown pigment can be quantified relative to normal hemoglobin on the basis of optical density. Hemoglobin from annelids shows characteristic absorption maxima at 574 and $538 \mathrm{~nm}$ which are markedly decreased when brown pigment is formed. This, together with a slight effect of brown pigment on the absorbance at $510 \mathrm{~nm}$ makes it possible to use the following ratios as indices of the hemoglobin purity and the proportion of brown pigment. The relative purity of hemoglobin (RPH) is calculated as the optical density ratio $538 \mathrm{~nm}: 280 \mathrm{~nm}$ and the relative proportion of brown pigment (RPB) as the optical density ratio $510 \mathrm{~nm}: 538 \mathrm{~nm}$. The significance of brown pigment for the sulfide oxidation activity in the 2 nereids was tested by comparison with $A$. marina and human blood. In order to make this comparison the ratio of RPB:RPH was used to compensate for any differences in sampling efficiency The sulfide oxidation activity was measured with the benzyl viologen assay at a sulfide concentration of $5 \mathrm{mM}$.

Long-term tolerance. Experiments were performed in open flow systems using natural sediment in the aquaria (Fig. 1). This made it possible to study the effect of hypoxia separately from the effect of sulfide. Although chemically unstable, a mixture of sulfide and oxygen can be maintained in an open flow system, which is impossible under static conditions. Poly-

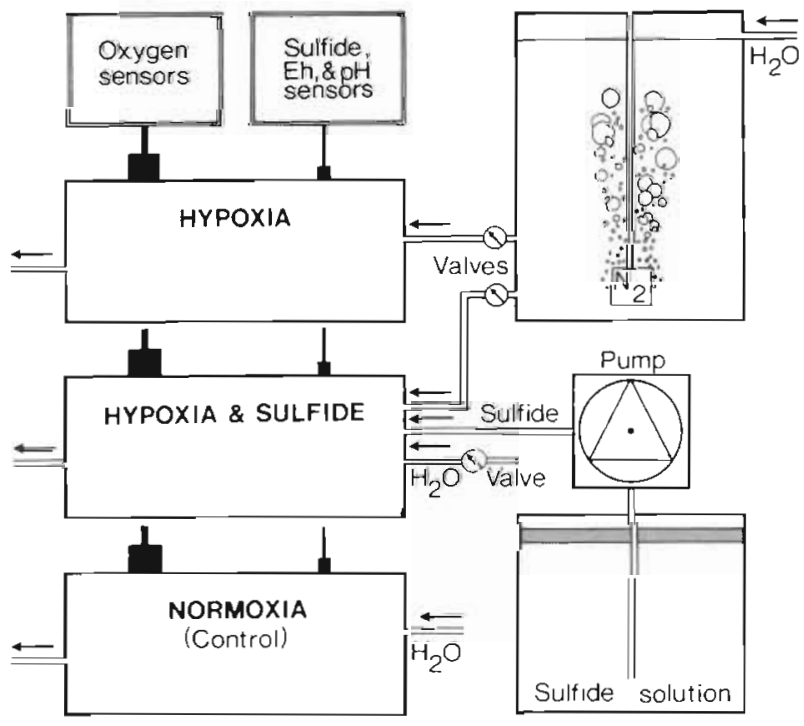

Fig. 1. Experimental set up for the study of long-term tolerance to hypoxia and sulfide in Nereis diversicolor and $N$. virens chaetes were kept for 1 wh at $100 \%$ oxygen saturation prior to experiments. One flow system was kept hypoxic (i. e. ca $10 \%$ oxygen saturation), one hypoxic with sulfide, and one normoxic (control). Thirty specimens were used in each flow system. A fresh sulfide stock solution ( $5 \mathrm{mM}$ ) was prepared every day by the addition of $\mathrm{Na}_{2} \mathrm{~S}$ to deoxygenated seawater. To prevent oxygen diffusion from the air, the surface of the stock solution was covered with paraffin oil. The amount of oxygen and sulfide in the flow system was controlled by adjustments of the appropriate valves (see Fig. 1), and measured daily as $\mathrm{pO}_{2}$, Eh, and sulfide, by means of polarographic oxygen sensors (YSI model 57), Pt electrodes, and Ag-AgS electrodes, respectively. The $\mathrm{pH}$ value (Radiometer PHM80) of the flow system was measured occasionally. The same set of measurements was performed in the hypoxic flow system and in the control flow system. At a fixed time each day, the behavior of the polychaetes was observed and dead individuals counted and removed. A specimen was considered to be above the sediment when half of it was visible. Specimens were considered dead when failing to respond when touched or to recover within $2 \mathrm{~h}$ in normal seawater. At the start and finish of the experiments, sulfide oxidizing ability was measured using the benzyl viologen technique. One group of polychaetes was also allowed 1 wk of recovery in normal seawater before measurement.

Short-term tolerance. Experiments were performed in a static system without sediment. Containers (vol: $200 \mathrm{ml}$ with $100 \mathrm{ml}$ anoxic seawater and an increasing series of sulfide concentrations were used. The sulfide concentrations in the tanks were determined continuously during the experiments with AgS-S electrodes mounted in the lids of the tanks. In each experiment 10 polychaetes were used. They were incubated for 30 min and allowed $2 \mathrm{~h}$ of recovery in fresh seawater before mortality was determined. The mortalities in both normoxia and anoxia were used as controls.

\section{RESULTS AND DISCUSSION}

\section{Enzymatic sulfide oxidation in different tissues}

Samples of body wall, gut wall, intestinal fluid, blood, and coelomic fluid from Nereis diversicolor showed different levels of sulfide oxidation activity (Fig. 2). Apart from the coelomic fluid which does not catalyze sulfide oxidation, all sample types exhibited Michaelis-Menten kinetics (Table 1). Blood, intestinal fluid, and intestinal wall had the highest activities. The maximal catalytic rate $\left(V_{\max }\right)$ of the body wall was not significantly different from the basal level and the observed activity reflects a non-specific catalysis 


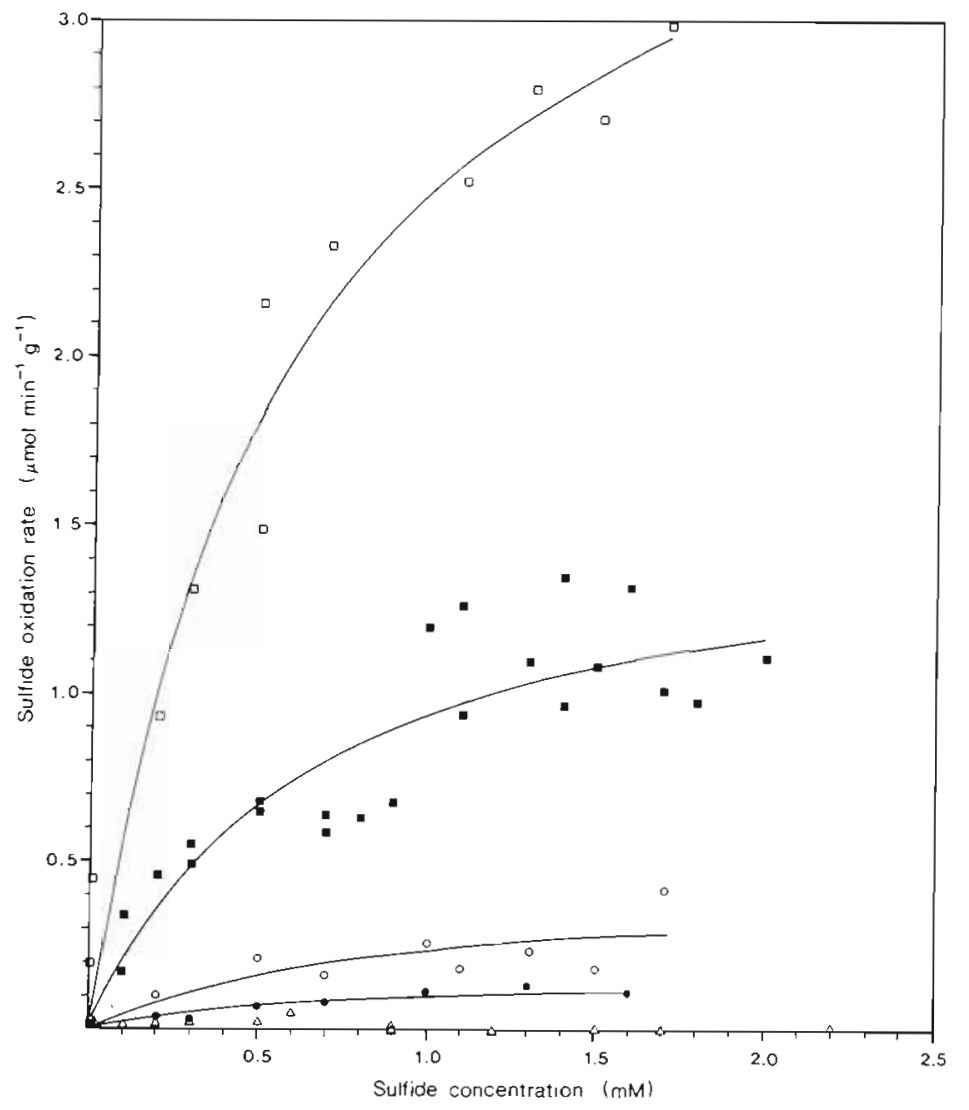

Fig. 2. Nereis diversicolor. Sulfide oxidation activity in homogenates of different tissues as a function of sulfide concentration. (4) Coelomic fluid; ( $\bullet$ body wall; (c)

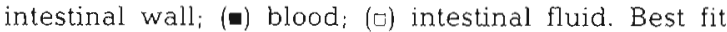
curves were calculated using a non-linear regression program
The sulfide oxidation activity at $5 \mathrm{mM}$ sulfide for different tissues of Nereis diversicolor and $N$. virens kept under normoxia is shown in Table 2. The body wall and coelomic fluid of the 2 species did not catalyze sulfide oxidation significantly above the basal level. As in the case of $N$. diversicolor, the blood, intestinal fluid, and intestinal wall of $N$. virens showed the capability of sulfide detoxification, but at a significantly lower level. Sulfide detoxification is localized in distinct tissues or body fluids, but this information is lost when working with homogenates of whole animals (Table 2), which, therefore, is an inappropriate way of screening sulfide detoxification activity. Sulfide oxidation activity of the blood of the 2 species showed Michaelis-Menten kinetics (Fig. 3). The slope of the regression line and the intercept in $N$. diversicolor are $0.43 \pm 0.02(\mathrm{SE})$ and $0.44 \pm 0.04(\mathrm{SE})$, respectively $\left(\mathrm{R}^{2}\right.$ $=0.88 ; \mathrm{p}<0.001)$, giving a half-saturation constant $\left(K_{m}\right)=1.0 \mathrm{mM}$ and $V_{\max }=2.3 \mu \mathrm{mol} \mathrm{min}{ }^{-1} \mathrm{FW} \mathrm{g}^{-1}$. In $N$. virens the slope of the regression line and the intercept are $2.39 \pm 0.16$ (SE) and $0.68 \pm 0.19$ (SE) respectively $\left(R^{2}=0.93 ; p<0.001\right)$, giving $K_{m}=$ $3.5 \mathrm{mM}$ and $V_{\max }=1.5 \mu \mathrm{mol} \mathrm{min}{ }^{-1} \mathrm{FW} \mathrm{g}^{-1}$. This suggests that $N$. diversicolor is superior to $N$. virens regarding catalytic sulfide oxidation. Human blood (Fig. 3) yields a slope of the regression line and an intercept of $5.30 \pm 0.41$ (SE) and $0.46 \pm 0.37$ (SE), respectively $\left(\mathrm{R}^{2}=0.93 ; \mathrm{p}<0.0001\right)$, giving $\mathrm{K}_{\mathrm{m}}=$ $11.5 \mathrm{mM}$ and $V_{\max }=2.2 \mu \mathrm{mol} \mathrm{min} \mathrm{mW} \mathrm{g}^{-1}$.

The intestinal fluid of the 2 species catalyzes the oxidation of sulfide (Table 2). As in the case of the blood, the intestinal fluid of Nereis diversicolor oxidized sulfide with a significantly higher activity than did the intestinal fluid of $N$ virens. In both species it had a black transparent color and foamed easily, possibly indicating presence of bile. Microscopic observations revealed only few rod-shaped bacteria with a length of 3 to $5 \mu \mathrm{m}$.

Table 1. Nereis diversicolor. Michaelis-Menten kinetics of homogenates of different tissues. The half-saturation constant $\left(\mathrm{K}_{\mathrm{m}}\right)$ and the maximal catalytic rate $\left(\mathrm{V}_{\text {max }}\right)$ were calculated using a non-linear regression program

\begin{tabular}{|lcccc|}
\hline Sample & $\begin{array}{c}K_{m} \\
(\mathrm{mM})\end{array}$ & $\begin{array}{c}V_{\max } \\
\left(\mu \mathrm{mol} \mathrm{min} \mathrm{min}^{-1}\right. \\
\left.g^{-1}\right)\end{array}$ & $\mathrm{R}^{2}$ & $\mathrm{p}$-value \\
\hline Coelomic fludd & - & - & - & - \\
Intestinal wall & $0.89 \pm 1.15$ & $0.44 \pm 0.25$ & 0.92 & $<0.001$ \\
Body wall & $1.05 \pm 0.52$ & $0.21 \pm 0.05$ & 0.98 & $<0.001$ \\
Blood & $0.68 \pm 0.22$ & $1.57 \pm 0.20$ & 0.97 & $<0.001$ \\
Intestinal fluid & $0.56 \pm 0.14$ & $3.95 \pm 0.36$ & 0.99 & $<0.001$ \\
\hline
\end{tabular}


Table 2. Nereis diversicolor and $N$. virens. Sulfide oxidation activity at $5 \mathrm{mM}$ sulfide in homogenates of different tissues under different long-term experimental conditions. Activities are expressed in $\mu \mathrm{mol} \mathrm{min}^{-1} \mathrm{~g}^{-1}$ and presented with standard errors. Number of samples in parentheses

\begin{tabular}{|c|c|c|c|c|c|c|}
\hline $\begin{array}{l}\text { Experimental } \\
\text { condition }\end{array}$ & Blood & $\begin{array}{l}\text { Intestinal } \\
\text { fluid }\end{array}$ & $\begin{array}{l}\text { Intestinal } \\
\text { wall }\end{array}$ & $\begin{array}{l}\text { Body } \\
\text { wall }\end{array}$ & $\begin{array}{l}\text { Coelomic } \\
\text { fluid }\end{array}$ & $\begin{array}{l}\text { Whole } \\
\text { specimen }\end{array}$ \\
\hline \multicolumn{7}{|c|}{ N. diversicolor } \\
\hline Normoxia & $2.18 \pm 0.31(28)$ & $5.69 \pm 1.42(3)$ & $0.48 \pm 0.12\{3\rceil$ & $0.31 \pm 0.05$ & $0.06 \pm 0.06$ & $0.36 \pm 0.05(13)$ \\
\hline Hypoxia & $0.51 \pm 0.10(8)$ & $0.53 \pm 0.23(3)$ & $0.02 \pm 0.01(3)$ & $0.09 \pm 0.02(3)$ & $0.19 \pm 0.09(3)$ & - \\
\hline Hypoxia + sulfide & $0.18 \pm 0.04$ & $4.40 \pm 1.50$ & $0.10 \pm 0.06(2)$ & $0.22 \pm 0.09$ & $0.22 \pm 0.22$ & - \\
\hline $\begin{array}{l}\text { Post hypoxia + } \\
\text { sulfide }\end{array}$ & $1.80 \pm 0.61(4)$ & - & - & - & - & - \\
\hline \multicolumn{7}{|c|}{$N$. virens } \\
\hline Normoxia & $0.62 \pm 0.05(8)$ & $0.91 \pm 0.24(3)$ & $0.28 \pm 0.02$ & $0.10 \pm 0.01(3)$ & $0.07 \pm 0.07$ & $0.08 \pm 0.01$ \\
\hline Hypoxia & $0.59 \pm 0.12(4)$ & $0.72 \pm 0.32$ & $0.16 \pm 0.04(3)$ & $0.07 \pm 0.00(3)$ & $0.12 \pm 0.03$ & - \\
\hline Hypoxia + sulfide & $0.57 \pm 0.06$ & $1.15 \pm 0.35$ & $0.66 \pm 0.04(3)$ & $0.07 \pm 0.01(3)$ & $0.32 \pm 0.11(3)$ & - \\
\hline $\begin{array}{l}\text { Post hypoxia + } \\
\text { sulfide }\end{array}$ & $0.60 \pm 0.07$ & - & - & - & - & - \\
\hline
\end{tabular}

\section{Significance of brown pigment}

The relative purity of hemoglobin, the relative proportion of brown pigment, and the sulfide oxidation activity at $5 \mathrm{mM}$ sulfide in blood from Nereis diversicolor, N. virens, Arenicola marina, and a human sample are shown in Table 3. A correlation analysis of the sulfide oxidation activity versus the ratio $R P B: R P H$ gives a near to perfect correlation $\left(R^{2}=\right.$ $0.99 ; \mathrm{p}<0.005)$. $N$. virens possessed relatively little brown pigment relative to hemoglobin and had a sulfide oxidation activity close to that of human blood. The blood of $A$. marina and $N$. diversicolor had higher brown pigment to hemoglobin ratios and showed significantly higher sulfide oxidation activity.
$N$. diversicolor had more brown pigment relative to hemoglobin and a higher sulfide oxidation activity than A. marina.

Patel \& Spencer (1963b) believed the brown pigment to be present in vitro as well as in vivo and to form autocatalytically from hemoglobin by irreversible oxidation when the blood is exposed to sulfide. They believed the catalytic effect to be due to a loose association of prosthetic groups and protein, making the pigment behave like free heme, which is known to catalyze sulfide oxidation (Sörbo 1958). However, in the blood of the related polychaete Abarenicola affinis no oxidized heme compounds are present or formed during exposure to sulfide and the brown pigment is refuted, and considered an artefact due to
Fig. 3. Nereis diversicolor, $N$. virens, Homo sapiens. Double-reciprocal (LineweaverBurk) plot of sulfide oxidation activity of blood as a function of sulfide concentration. ( $\mathbf{a})$. diversicolor; ( $\square$ ) N. virens; (o) human blood. Best fit straight linies were calculated using a linear regression program

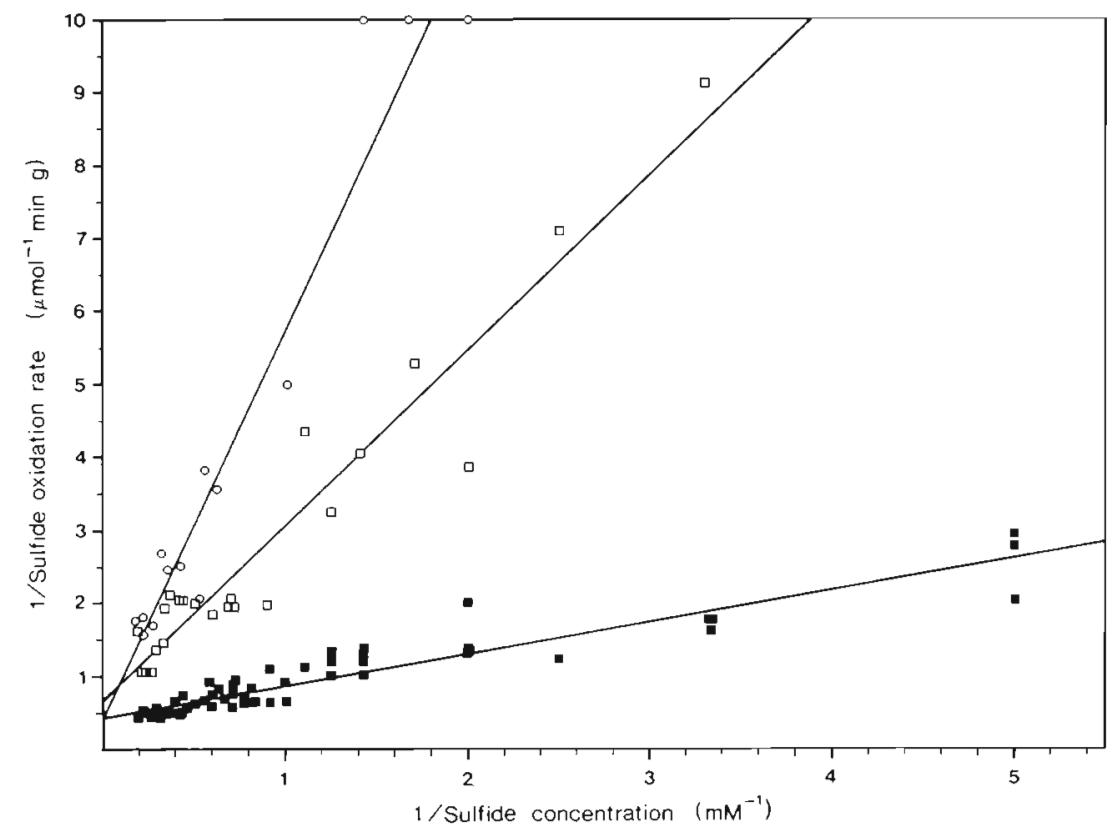


sample preparation (Wells \& Pankhurst 1980). Although oxidized heme compounds have been suggested to occur in annelids only in individuals kept under poor laboratory conditions (Mangum 1976), the diversity of adaptations to sulfide (see e.g. Childress et al. 1987, Powell et al. 1987) means that the absence of such a pigment in one species is not evidence that it is absent in other species. Patel \& Spencer (1963b) found no difference in sulfide oxidation activity between pure hematin and the brown pigment. In fact, the photometric quantification of the pigment is based on wavelengths corresponding to the absorption maxima of hematin (Patel \& Spencer 1963a). This makes it possible that the sulfide oxidation activity observed by Patel \& Spencer and in the present study is in fact catalyzed by hematin. The term 'brown pigment' may therefore not describe any real phenomenon. Hematin-catalyzed sulfide axidation has recently been demonstrated in the echiuran Urechis caupo and in the bivalves Solemya reidi, Calyptogena magnifica and Lucinoma annulata (Powell \& Arp 1989). The finding that the present sulfide oxidation activity correlates to the relative content of a brown pigment is valid whether the heme is free or loosely bound to a protein.

\section{Tolerance to long- and short-term exposure to sulfide and to hypoxia}

\section{Long-term survival}

The physical and chemical conditions in the experiments on long-term tolerance to hypoxia and to sulfide are listed in Table 4 . Tolerance to hypoxia and hypoxia plus sulfide expressed as surviving individuals (\%) as a function of exposure time is shown in Fig. 4. The observed differences in sulfide oxidation activity in the 2 species are reflected in their long-term tolerances to sulfide. In Nereis diversicolor practically all specimens survived for at least $16 \mathrm{~d}$. Mortality was higher under hypoxia plus sulfide than under hypoxia alone. In $N$. virens, mortality occurred within $2 \mathrm{~d}$ under hypoxia as well as under hypoxia plus sulfide. After $6 \mathrm{~d}$, mortality was highest for the sulfide-treated worms. In hypoxia with sulfide, $50 \%$ of $N$. virens were dead within $8 \mathrm{~d}$ as compared to ca 24 d (extrapolated from Fig. 4) for $N$. diversicolor. In the control experiment (normoxia) survival was $100 \%$ (not shown). Thus, $N$. diversicolor is more tolerant to hypoxia and to sulfide than is $N$. virens, but in both species mortality is increased when sulfide is present. The flow-through experiments repre-

Table 3. Nereis diversicolor, $N$. virens, Arenicola marina and Homo sapiens. Reiative purity of hemoglobin and brown pigment together with sulfide oxidation activity at $5 \mathrm{mM}$ sulfide in blood. Number of samples in parentheses

\begin{tabular}{|lcccc}
\hline $\begin{array}{l}\text { Sample } \\
\text { type }\end{array}$ & $\begin{array}{c}\text { Relative purity of } \\
\text { hemoglobin (RPH) }\end{array}$ & $\begin{array}{c}\text { Relative proportion of } \\
\text { brown pigment (RPB) }\end{array}$ & Ratio of RPB to RPH & $\begin{array}{c}\text { Sulfide oxidation activity } \\
\text { at 5 mM sulfide }\end{array}$ \\
\hline $\begin{array}{l}\text { Nereis diversicolor }(\mathrm{n}=5) \\
\text { Nereis virens }(\mathrm{n}=5)\end{array}$ & $0.10 \pm 0.02$ & $0.21 \pm 0.01$ & $0.37 \pm 0.02$ & 1.90 \\
Arenicola marina $(\mathrm{n}=3)$ & $0.16^{\mathrm{a}}$ & $0.48^{\mathrm{d}}$ & 3.7 & 0.86 \\
Homo sapiens $(\mathrm{n}=2)$ & $0.28 \pm 0.01$ & $0.34 \pm 0.01$ & 3.0 & 1.60 \\
a & & & 1.2 & 0.66 \\
\hline
\end{tabular}

Table 4. Nereis diversicolor and $N$. virens. Experimental conditions in long-term tolerance experiments to hypoxia and sulfide (with standard error). nd: not detectable

\begin{tabular}{|c|c|c|c|c|}
\hline & $\begin{array}{l}\text { Oxygen partial } \\
\text { pressure } \\
\text { (Torr) }\end{array}$ & $\begin{array}{c}\text { Redox } \\
\text { potential } \\
(\mathrm{mV})\end{array}$ & $\begin{array}{c}\text { Sulfide } \\
\text { concentration } \\
(\mu \mathrm{M})\end{array}$ & $\begin{array}{c}\mathrm{pH} \\
\left(-\log \left[\mathrm{H}^{+}\right]\right)\end{array}$ \\
\hline \multicolumn{5}{|l|}{ Hypoxia + sulfide } \\
\hline N. diversicolor & $24 \pm 5$ & $83 \pm 16$ & $187 \pm 31$ & 8.2 \\
\hline N. virens & $15 \pm 1$ & $113 \pm 33$ & $172 \pm 62$ & 8.0 \\
\hline \multicolumn{5}{|l|}{ Hypoxia } \\
\hline N. diversicolor & $20 \pm 5$ & $246 \pm 12$ & nd & 8.2 \\
\hline N. virens & $15 \pm 1$ & $250 \pm 14$ & nd & 8.0 \\
\hline \multicolumn{5}{|l|}{ Normoxia (control) } \\
\hline N. diversicolor & $146 \pm 14$ & $329 \pm 10$ & nd & 8.1 \\
\hline$N$. virens & $146 \div 13$ & $333 \pm 12$ & nd & 8.0 \\
\hline
\end{tabular}




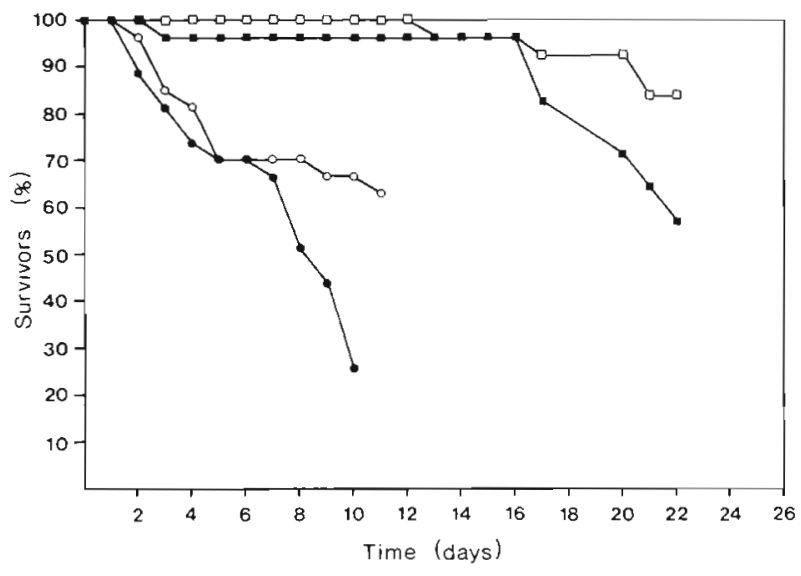

Fig. 4. Nereis diversicolor and $N$. virens. Long-term survival as a function of exposure time. N. diversicolor: ( $\square$ ) hypoxia, ( $\square$ ) hypoxia with presence of sulfide. $N$. virens: (0) hypoxia, $(\bullet)$ hypoxia with presence of sulfide

sent a more realistic simulation of the situation in sediments than do experiments using static conditions. Still, the present hypoxia plus sulfide results accord with the trends found by Theede et al. (1973) and the hypoxia results accord with those of Kristensen (1983a).

\section{Behavior during long-term exposure}

Exposure to hypoxia and sulfide changed the behavior of both species. They stopped feeding. Also, when exposed to hypoxia with sulfide or hypoxia alone they left the sediment as seen in Fig. 5. The rate at which they left the sediment differed in the 2 species. In the hypoxia experiment with Nereis diversicolor ca $8 \%$ of the experimental population were seen on the sediment surface after $10 \mathrm{~d}$. When hypoxia was accompanied by sulfide ca $35 \%$ of the specimens were seen on the sediment surface in a comparable period. After $10 \mathrm{~d}$ of hypoxia and hypoxia with sulfide, $17 \%$ and $100 \%$ respectively of $N$. virens were present on the sediment surface. The most significant difference in the behavior of the 2 species was in the hypoxia plus sulfide experiment, where all $N$. virens were seen on the surface after ca $9 \mathrm{~d}$. In the control experiments (normoxia) less than $7 \%$ appeared on the surface. $N$. diversicolor always come to the sediment surface head first, in contrast to $N$. virens, which come up tail first. In both species the individuals seen on the sediment surface were relatively inactive.

Sulfide oxidation activity during long-term exposure

The benzyl viologen assays from the long-term tolerance experiments are shown in Table 2. No adaptation was found for the 2 species. In fact, the sulfide oxidation activity found in Nereis diversicolor blood under hypoxia

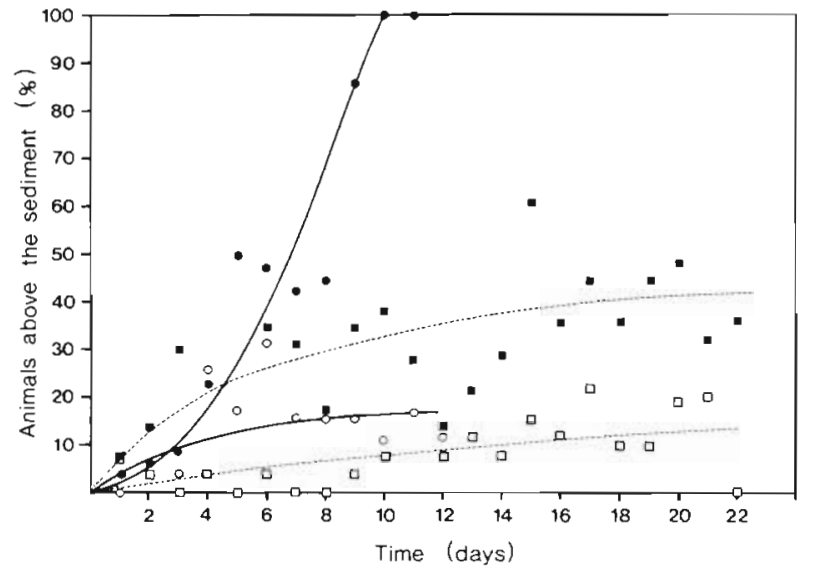

Fig. 5. Nereis diversicolor and $N$, virens. Percentage found above the sediment as a function of exposure time to hypoxia and hypoxia with presence of sulfide. $N$. diversicolor, broken lines: (0) hypoxia, ( $)$ hypoxia with presence of sulfide. $N$. virens, solid lines: (0) hypoxia, ( $\bullet$ hypoxia with presence of sulfide. Lines fitted by eye

and hypoxia plus sulfide was significantly lower than the activity under normoxia. The post hypoxia and sulfide measurement (Table 2) shows that the sulfide oxidation activity in the blood after recovery was the same as in the prior experiment, indicating no autocatalysis of brown pigment. In $N$. diversicolor blood, the higher sulfide oxidation activity is lost during hypoxia and sulfide. Whether the physiological reason is insufficient supply of oxygen for the oxidation of sulfide to thiosulfate or merely a general exhaustion of the polychaete is not known. However, the result shows that the high sulfide oxidation activity in $N$. diversicolor can only be maintained when oxygen is available. The assay of $N$. virens blood did not show any significant alterations, suggesting that the sulfide oxidation activity observed in the blood of this species is in part due to some non-specific activity (i. e. metal ions and proteins). The decrease in sulfide oxidation activity in the intestinal and body wall may be due to a similar mechanism as in the blood; however, the sample size is small so conclusions should be made with reservation. No significant changes were observed for the intestinal wall, body wall, and coelomic fluid in either of the 2 species. The decrease in sulfide oxidation activity in the intestinal fluid is explainable from the observation that all individuals stopped feeding during the experiments. Therefore, most specimens used in the assay did not contain the characteristic fluid observed in the intestine under normoxia.

\section{Survival during short-term exposure}

The acute toxicity of sulfide to the 2 species is shown in Fig. 6. Concentration is expressed as $\mathrm{mM}$ FW $\mathrm{g}^{-1}$, since the size of the polychaetes is important 


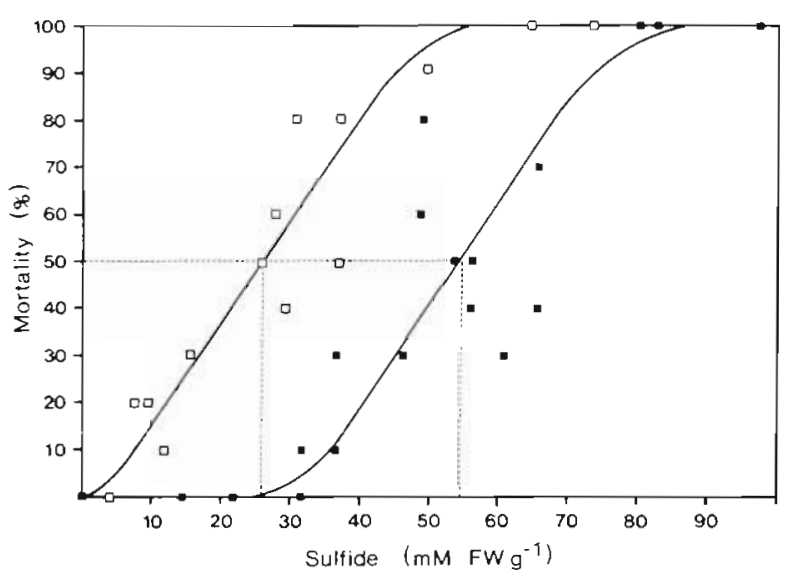

Fig. 6. Nereis diversicolor and $N$. virens. Mortality after shortterm exposure to anoxia and sulfide as a function of sulfide concentration per g fresh weight. ( $N$ ) diversicolor; ( $) N$ virens. Solid lines fitted by eye, broken lines show $\mathrm{LD}_{50}$ of the 2 species

due to the short exposure time when small individuals tend to die first. The mean fresh weights of Nereis diversicolor and $N$. virens were $410.80 \pm 36.40 \mathrm{mg}^{\text {ind }}$. $^{-1}$ and $693.77 \pm 87.37 \mathrm{mg}$ ind $^{-1}$, respectively. This way of representing the data emphasises the difference between the species, but even when the data is expressed in terms of sulfide concentration, ignoring the size differences, $N$. diversicolor shows a higher survival. The $\mathrm{LD}_{50}$ in $N$. diversicolor and $N$. virens is ca $54 \mathrm{mM} \mathrm{g}^{-1}$ and $26 \mathrm{mM} \mathrm{g}^{-1}$, respectively. Thus, the acute toxicity of sulfide in $N$. virens is about twice that of $N$. diversicolor. The experiments were performed under anoxic conditions and the acute toxicity may reflect a situation in which the polychaetes are establishing themselves in tubes penetrating anoxic parts of the sediment. Survival was $100 \%$ in both control experiments.

\section{Ecological implications}

The distributions of Nereis diversicolor and $N$. virens are known to be limited by environmental factors such as sediment, temperature, and salinity (HartmannSchröder 1971, Kristensen 1983b, 1988), but coexistence is physiologically possible in a wide range of these conditions. However, in nature, the species show habitat separation due to interference competition, that is, interspecific aggression and territorial behavior (Kristensen 1988, who described the relation by writing: Nereis diversicolor only stays where it is allowed to stay'). In Vellerup Bay, there is a broad zone of overlap between the 2 species, due to migration from high density areas. The distribution of the species within this zone is not explainable only in terms of sediment grain size, salinity and temperature. The areas where $N$. diversicolor is allowed to stay is conditioned by some additional environmental factor. During a preliminary study of the sampling area, sulfide was found to be very inhomogeneously distributed and $N$. diversicolor was generally in the sulfide-rich patches. That is to say, the higher sulfide detoxification in $N$. diversicolor allows it to stay in patches where the exposure to sulfide is too high for $N$. virens. The dispersal of the 2 species within the zone of possible coexistence observed by Kristensen (1988) and myself is thus explainable in terms of sulfide.

Severe hypoxia in marine habitats is a correlate of the presence of sulfide and so it is reasonable to assume that the ability to withstand hypoxia correlates with tolerance to sulfide. In the present study, Nereis diversicolor was shown to survive hypoxia with presence of sulfide for at least $3 \mathrm{wk}$ while $N$. virens survived only ca $10 \mathrm{~d}$ under the same conditions. In contrast to $N$. virens, $N$. diversicolor is thus able to inhabit more nutrientenriched environments where fluctuation in oxygen tensions and exposure to sulfide may occur.

The sulfide oxidation activity found in the fluid from the anterior region of the intestine in both nereids could have physiological importance in sulfide detoxification, as both species ingest sediment. The intestinal wall absorbs hydrogen sulfide 100 times faster than oxygen (Denis \& Reed 1927). Any hydrogen sulfide present in the ingested sediment will thus be a physiological problem. If the polychaete at the same time has acid digestion the problem becomes even greater due to the $\mathrm{pH}$ dependence of the sulfide species. In the oesophagus of Nereis virens excretion of trypsin has been shown by Michel \& DeVillez (1979), indicating alkaline digestion in this species. No information on the digestion in $N$. diversicolor could be found in the literature. However, neglecting the possible importance of $\mathrm{pH}, N$. diversicolor is in nature exposed to higher sulfide concentrations in the intestine than $N$. virens, as the former lives in more reduced sediments than the latter. This corresponds to the present results, where $N$. diversicolor has a significantly higher sulfide oxidation activity in the intestinal fluid than does $N$. virens. The actual site of this sulfide detoxification is not known. The presence of enzymes or any biological correlation between the $\mathrm{pH}$, the concentration of bacteria, and the sulfide oxidation activity of the intestinal fluid of the 2 species is to be evaluated in future studies.

Acknowledgements. I thank Prof. Tom Fenchel and Dr Lars Hagerman for constructive criticism and discussion. I am indebted to Jeanne Johansen and Janne Ravensholt for assistance with experimental work and to Torkel Gissel Nielsen for his donation of blood. This study was supported by the Danish Natural Science Research Council grant nos. 11-6737 


\section{LITERATURE CITED}

Anderson, A. E., Childress, J. J., Favuzzi, J. A. (1987). Net uptake of $\mathrm{CO}_{2}$ driven by sulphide and thiosulphate oxidation in the bacterial symbiont-containing clam Solemya reidi. J. exp. Biol. 133: 1-31

Baxter, C. F., VanReen, R. (1958a). Some aspects of sulfide oxidation by rat-liver preparations. Biochim. Biophys. Acta 28: $567-573$

Baxter, C. F., VanReen, R., Pearson, P. B., Rosenberg, C. (1958b). Sulfide oxidation in rat tissues. Biochim. Biophys Acta 27: 584-591

Cavanaugh, C. M. (1985). Symbioses of chemoautrotrophic bacteria and marine invertebrates from hydrothermal vents and reducing sediments. Bull. Biol. Soc. Wash. 6: $373-388$

Childress, J. J., Felbeck, H., Somero, G. N. (1987). Symbiosis in the deep sea. Scient. Am. 256 (5): 106-112

Corliss, J. B., Dymond, J., Gordon, L., Edmond, J. M., Herzen Von, R. P., Ballard, R. D., Green, K., Williams, D., Bainbridge, A., Crane, K., Andel Van, T. H. (1979). Submarine thermal springs on the Galapagos rift. Science 203: 1073-1083

Curtis, C. G., Bartholomew, T. C., Rose, F. A., Dodgson, K. S (1972). Detoxication of sodium ${ }^{35} \mathrm{~S}$-Sulphide in the rat. Biochem. Pharmac. 21: 2313-2321

Degn, H., Kristensen, B. (1981). Low sensitivity of Tubifex sp. respiration to hydrogen sulfide and other inhibitors. Comp Biochem. Physiol. 69B: 809-817

Denis, W., Reed, L. (1927). The action of blood on sulfides. J biol. Chem. 72: 385-394

Dziewiatkowski, D. D. (1945). Fate of ingested sulfide sulfur labeled with radioactive sulfur in the rat. J. biol. Chem. 161: 723-729

Edmond, J. M., Von Damm, K. L., McDuff, R. E., Measures, C. I (1982). Chemistry of hot springs on the East Pacific Rise and their effluent dispersal. Nature, Lond. 297: 187-191

Evans, C. L. (1967). The toxicity of hydrogen sulphide and other sulphides. Q. JI exp. Physiol. 52: 231-248

Fenchel, T. (1969). The ecology of marine microbenthos IV Structure and function of the benthic ecosystem, its chemical and physical factors and the microfauna communities with special reference to the ciliated protozoa. Ophelia 6 : $1-182$

Fenchel, T. M., Riedl, R. J. (1970). The sulfide system: a new biotic community underneath the oxidized layer of marine sand bottoms. Mar. Biol. 7: 255-268

Haggard, H. W. (1921). The fate of sulfides in the blood. J biol. Chem. 49:519

Hansen, M. H., Ingvorsen, K., Jørgensen, B. B. (1978). Mechanisms of hydrogen sulfide release from coastal marine sediments to the atmosphere. Limnol. Oceanogr. 23: $68-75$

Hartmann-Schröder, G. (1971). Annelida, Borstenwürmer, Polychaeta. In: Dahl, M., Peus, F. (eds.) Die Tierwelt Deutschlands und der angrenzenden Meeresteile nach ihren Merkmalen und nach ihrer Lebensweise. Fischer, Jena, p. 189-212

Jacubowa, L., Malm, E. (1931). Die Beziehungen einiger Benthos-Formen des Schwarzen Meeres zum Medium. Biol. Zbl. 51: 105-116

Jones, M. L. (ed.) (1985). Hydrothermal vents of the eastern Pacific: an overview (Symposium). Bull. Biol. Soc. Wash. 6: $1-566$

Jørgensen, B. B. (1977). The sulfur cycle of a coastal marine sediment (Limfjorden, Denmark). Limnol. Oceanogr. 22: $814-832$
Kristensen, E. (1983a). Ventilation and oxygen uptake by three species of Nereis (Annelida: Polychaeta). I. Effects of hypoxia. Mar. Ecol. Prog. Ser. 12: 289-297

Kristensen, E. (1983b). Ventilation and oxygen uptake by three species of Nereis (Annelida: Polychaeta). II. Effects of temperature and salinity changes. Mar. Ecol. Prog. Ser. 12: 299-306

Kristensen, E. (1988). Factors influencing the distribution of nereid polychaetes in Danish coastal waters. Ophelia 29: $127-140$

Lonsdale, P. (1977). Clustering of suspension-feeding macrobenthos near abyssal hydrothermal vents at oceanic spreading centers. Deep Sea Res. 24: 857-863

Mangum, C. P. (1976). Primitive respiratory adaptations. In: Newell, R. C. (ed.) Adaptation to environment. Butterworths, London, p. 191-278

McKellar, R. C., Sprott, G. D. (1979). Solubilization and properties of a particulate hydrogenase from Methanobacterium Strain G2R. J. Bacteriol. 139: 231-238

Meyers, M. B., Fossing, H., Powell, E. N. (1987). Microdistribution of interstitial meiofauna, oxygen and sulfide gradients, and the tubes of macro-infauna. Mar. Ecol. Prog. Ser. 35: 223-241

Meyers, M. B., Powell, E. N., Fossing, H. (1988) . Movement of oxybiotic and thiobiotic meiofauna in response to changes in pore-water oxygen and sulfide gradients around macroinfaunal tubes. Mar. Biol. 98: 395-414

Michel, C., DeVillez, E. J. (1979). Secretion of trypsin in the oesophagus of Nereis virens Sars (Polychaeta: Errantia). A biochemical and histological study. Biol. Bull. mar. biol. Lab., Wood Hole 156: 224-233

National Research Council, Division of Medical Science, subcommittee on Hydrogen Sulfide (1979). Hydrogen sulfide. University Press, Baltimore

Oertzen, J.-A. von, Schlungbaum, G. (1972). Experimentellökologische Untersuchungen über $\mathrm{O}_{2}$-Mangel und $\mathrm{H}_{2} \mathrm{~S}$ Resistenz an marinen Evertebraten der westlichen Ostsee. Beitr. Meeresk. 29: 79-91

Oeschger, R., Schmaljohann, R. (1988). Association of various types of epibacteria with Halicryptus spinulosus (Priapulida). Mar. Ecol. Prog. Ser. 48: 285-293

Patel, S., Spencer, C. P. (1963a). Studies on the haemoglobin of Arenicola marina. Comp. Biochem. Physiol. 8: 65-82

Patel, S., Spencer, C. P. (1963b). The oxidation of sulphide by the haem compounds from the blood of Arenicola marina. J. mar. bial. Ass. U. K. 43: 167-175

Peck, H. D. (1968). Energy-coupling mechanisms in chemoautotrophic bacteria. A. Rev. Microbiol. 22: 489-518

Powell, M. A., Arp, A. J. (1989). Hydrogen sulfide oxidation by abundant nonhernoglobin heme compounds in marine invertebrates from sulfide-rich habitats. J. exp. Zool. 249: 121-132

Powell, E. N., Crenshaw, M. A., Rieger, R. M. (1979). Adaptations to sulfide in the meiofauna of the sulfide system. I. ${ }^{35} \mathrm{~S}$-sulfide accumulation and the presence of a sulfide detoxification system. J. exp. mar. Biol. Ecol. 37: 57-76

Powell, E. N., Crenshaw, M. A., Rieger, R. M. (1980). Adaptations to sulfide in sulfide-system meiofauna. Endproducts of sulfide detoxification in three turbellarians and a gastrotrich. Mar. Ecol. Prog. Ser. 2: 169-177

Powell, M. A., Somero, G. N. (1985). Sulfide oxidation occurs in the animal tissue of the gutless clam, Solemya reidi. Biol. Bull. mar. biol. Lab., Woods Hole 169: 164-181

Powell, M. A., Somero, G. N. (1986). Hydrogen sulfide oxidation is coupled to oxidative phosphorylation in mitochondria of Solemya reidi. Science 233: 563-566

Powell, M. A., Vetter, R. D., Somero, G. N. (1987). Sulfide 
detoxification and energy exploitation by marine animals. In: Dejours, P., Bolis, L., Taylor, C. R., Weibel, E. R. leds.) Comparative physiology: life in water and on land. Fidia Research Series, IX-Liviana Press, Padova, p. 241-250

Rasmussen, E. (1973). Systematics and ecology of the Isefjord marine fauna (Denmark). Ophelia 11: 1-495

Siegel, L. M. (1975). Oxidation of reduced sulfur compounds in animals. In: Greenberg, D. M. (ed.) Metabolic pathways, Vol.3 (3rd edn). Metabolism of sulfur compounds. Academic Press, New York, p. 275-286

Southward, E. C. (1987). Contributions of symbiotic chemoautotrophs to the nutrition of benthic invertebrates. In: Sleigh, M. A (ed.) Microbes in the sea. John Wiley \& Sons, New York, p. 83-118

Sörbo, B. (1958). On the formation of thiosulfate from inorganic sulfide by liver and heme compounds. Biochim. Biophys. Acta 27: 324-329

This article was presented by Professor $T$ Fenchel, Helsingor, Denmark
Theede, H., Ponat, A., Hiroki, K., Schlieper, C. (1969). Studies on the resistance of marine bottom invertebrates to oxygendeficiency and hydrogen sulphide. Mar. Biol. 2: 325-337

Theede, H., Schaudinn, J., Saffé, F. (1973). Ecophysiological studies on four Nereis species of the Kjel Bay. Oikos suppl. 15: $246-252$

Vetter, R. D., Wells, M. E., Kurtsman, A. L., Somero, G. N. (1987). Sulfide detoxification by the hydrothermal vent crab Bathogrea thermydron and other decapod crustaceans. Physiol. Zool. 60(1): 121-137

Wells, R. M. G., Pankhurst, N. W. (1980). An investigation into the formation of sulphide and oxidation compounds from the haemoglobin of the lugworm Abarenicola affinis (Ashworth). Comp. Biochem. Physiol. 66C: 255-259

Yokoyama, E., Yoder, R. E., Frank, N. R. (1971). Distribution of ${ }^{35} \mathrm{~S}$ in blood and its excretion in urine of dogs exposed to ${ }^{35} \mathrm{SO}_{2}$. Archs environ. Hith 22: 389-395

Manuscript first received: August 15, 1989 Revised version accepted: October 18, 1989 